\title{
Glutamate-cysteine ligase deficiency
}

INSERM

\section{Source}

INSERM. (1999). Orphanet: an online rare disease and orphan drug data base. Glutamatecysteine ligase deficiency. ORPHA:33574

A disorder that is principally characterized by hemolytic anemia, (usually rather mild), however, the presence of neurological symptoms has also been reported. 